\title{
MINERAL RESOURCE POTENTIAL OF THE BEAVER CREEK WLDERNESS MCCREARY COUNTY, KENTUCKY
}

\author{
By \\ Kenneth J. Englund and Priscilla L. Johnson, U.S. Geological Survey \\ and \\ Richard W. Hammack and Robert B. Ross, Jr., U.S. Bureau of Mines
}

1983

Studies Related to Wilderness

Under the provisions of the Wilderness Act (Public Law 88-577, September 3, 1964) and related acts, the U.S. Geological Survey and U.S. Bureau of Mines have been conducting mineral surveys of wilderness and primitive areas. Areas officially designated as "wilderness," "wild," or "canoe" when the act was passed were incorporated into the National Wilderness Preservation System, and some of them are presently being studied. The act provided that areas under consideration for wilderness designation should be studied for suitability for incorporation into the Wilderness System. The mineral surveys constitute one aspect of the suitability studies. The act directs that the results of such surveys are to be made available to the public and be submitted to the President and the Congress. This report discusses the results of a mineral survey of the Beaver Creek Wilderness, Daniel Boone National Forest, McCreary County, Kentucky. The area was established as a wilderness by Public Law 93-622, January 3, 1975.

\section{MINERAL RESOURCE POTENTIAL SUMMARY STATEMENT}

The Beaver Creek Wilderness comprises 4,791 acres in the Daniel Boone National Forest, McCreary County, Ky. The area is located at the western edge of the Appalachian coal region and is within the highly dissected Cumberland Plateau section of the Appalachian Plateaus physiographic province. More than 99 percent of the surface rights are owned by the U.S. Government and more than 99 percent of the mineral rights of the area remain in private ownership.

The exposed stratigraphic section consists of a sequence of limestone, shale, and sandstone of Late Mississippian age along the lower valley slopes of Beaver Creek and its principal tributaries and an overlying sequence of sandstone, siltstone, shale, coal, and underclay of Early to Middle Pennsylvanian age on upper valley slopes and in broad uplands.

Coal, tentatively ranked as high-volatile A bituminous, is the most important mineral resource in the wilderness. It is suitable for use as steam coal, particularly following beneficiation to reduce the sulfur and ash content. Remaining coal resources are estimated to total 8.3 million short tons within the wilderness boundary. Of this total, the demonstrated remaining reserve base is estimated to be 5.2 million short tons; 4.2 million short tons is available to underground mining; 453,000 tons to strip mining, and 541,000 tons to auger mining. Estimated underground remaining reserves of wilderness coal are 2.1 million short tons at 50 percent recovery and 2.5 million short tons at 60 percent recovery. Strip and auger reserves are 356,000 short tons and 179,000 short tons, respectively.

The reserve base was also estimated for impacted coal, defined herein as coal within and beyond the wilderness boundary that cannot be mined except from drift entries and surface mines within the wilderness boundary. Impacted coal has a demonstrated remaining reserve base of 8.7 million short tons available to underground mining, 453,000 short tons to strip mining, and 541,000 short tons to auger mining. Estimated underground remaining reserves are 4.4 million short tons at 50 percent recovery and 5.2 million short tons at 60 percent recovery. Additional estimated remaining reserves include 356,000 short tons by strip mining and 179,000 short tons by auger mining.

Mineral resources that have a low potential include shale, sandstone, and limestone. Shale beds that were sampled and tested are suitable for the manufacture of products such as building brick, clay tile, and lightweight aggregate. Sandstone could be used for rough building stone and various special-purpose sands. Much of the limestone is of low quality and is relatively inaccessible. Sources of shale, sandstone, and limestone are available outside of the wilderness in proximity to transportation or markets. Commercial quantities of oil and gas may be under the wilderness, but drilling in the nearby area has been too shallow and too widely spaced to adequately test the $8,000 \mathrm{ft}$ of strata in the subsurface. No potential was found for metallic minerals. 


\section{INTRODUCTION}

The Beaver Creek Wilderness is in the Beaver Creek Cooperative Wildlife Management Area of the Daniel Boone National Forest, which is managed jointly by the U.S. Forest Service and the Kentucky Department of Fish and Wildlife Resources. It is in McCreary County, about $11 \mathrm{mi}$ southeast of Burnside, $\mathrm{Ky}$. , and is principally within the cliffline bordering the Beaver Creek drainage basin. The western edge of the wilderness is accessible from the north and south via U.S. Route 27 and Forest Service Road 50 (fig. 1). From the east the area can be reached via State Route 90 and Forest Service Road 46. The interior is accessible by foot along an abandoned Forest Service road and by several primitive trails that extend along the major streams.

The Beaver Creek Wilderness is located at the western edge of the Appalachian coal region and is within the highly dissected Cumberland Plateau section of the Appalachian Plateaus physiographic province. It is drained by Beaver Creek and its tributaries, which flow northeastward into Lake Cumberland, a reservoir on the Cumberland River about $1 \mathrm{mi}$ north of the wilderness. Altitudes range from about $730 \mathrm{ft}$ on the lower part of Beaver Creek to about $1,200 \mathrm{ft}$ at its headwaters. Vegetation varies from mixed hardwoods in the uplands to thickets of conifers, rhododendron, and laurel in moist protected areas along drainage courses and in coves.

\section{Previous Investigations}

Early geologic investigations in the area of the Beaver Creek Wilderness are presented in a description of coal beds along the western border of the eastern Kentucky coal field (Miller, 1910) and a geologic and structure contour map of McCreary County (Murphy and Miller, 1949). Huddle and others (1963) estimated the coal resources in McCreary County; Musser (1963), Collier and others (1964), and Collier, Pickering, and Musser (1970) described the mining activity and hydrologic effect of strip mining in parts of the Beaver Creek basin. Geologic maps of the Wiborg (Smith, 1970) and Hail (Smith and others, 1973) quadrangles include the area of the Beaver Creek Wilderness.

\section{Present Investigations}

U.S. Geological Survey (USGS) investigations were conducted in the fall of 1980 by Kenneth $J$. Englund, Nancy K. Teaford, and A. Henry Randall III. These studies included reconnaissance geologic mapping, description of coal beds and stratigraphic sections, and altimeter surveys of the altitudes of mapped units, mines, and coal prospects (Englund and Teaford, 1981). For a geochemical survey, A. E. Grosz (USGS) collected a total of 63 bulk samples of stream sediments, 8 samples of bedrock, and 3 panned concentrates of stream sediments. These samples, with the exception of the panned concentrates, were analyzed semiquantitatively in U.S. Geological Survey laboratories, Denver, Colo., for 31 elements, including metals having the greatest economic importance (Grosz and Siems, 1982).

U.S. Bureau of Mines (USBM) field reconnaissance was conducted by Richard W. Hammack and Robert B. Ross, Jr., in the fall of 1979 and summer of 1980 , with the assistance of Peter C.
Mory and Andrew E. Sabin (Hammack, in press). Thirteen coal and six bedrock samples were collected in or near the wilderness. All samples were analyzed spectrographically by the U.S. Bureau of Mines, Reno Metallurgy Research Center, Reno, Nev. Atomic absorption and other chemical analyses as well as petrographic studies were performed on selected samples. Clay and shale samples were evaluated for ceramic properties and lightweight aggregate potential by the U.S. Bureau of Mines, Tuscaloosa Research Center, Tuscaloosa, Ala. Coal samples were analyzed by the U.S. Department of Energy, Division of Solid Fuel Mining and Preparation, Coal Analysis, Pittsburgh, Pa. Additional fieldwork to verify critical coal-bed thickness points was conducted by the USGS and the USBM in the summer of 1981. A total of 40 adits, 33 prospects, and 52 exposures in and near the study area were examined, and coal samples were collected where possible.

\section{Acknowledgments}

The authors would like to express appreciation to Greenwood Land and Mining Company and to Doyle Mills, Chief Engineer, for providing: measured coal sections from a coal reconnaissance of Beaver Creek Wilderness performed by Russell Ping of Geological Associates; washability tests for samples from the Beaver Creek coal bed; maps delineating mineral rights owned or leased by Greenwood Land and Mining Company; maps showing locations of active and proposed underground mines in the Beaver Creek and Barren Fork coal beds; and a mine map for Greenwood Land and Mining Company's No. 6 Mine. Appreciation is also extended to U.S. Forest Service personnel, Somerset Ranger District, Daniel Boone National Forest, for their cooperation during all phases of the field investigaions.

\section{SURFACE- AND MINERAL-RIGHTS OWNERSHIP}

All surface rights in Beaver Creek Wilderness, except about 35 acres along Middle Fork, are in U.S. Government ownership (fig. 2). However, all mineral and oil and gas rights except two small tracts totalling about 24 acres are privately owned. Greenwood Land and Mining Company controls most of the minerals and oil and gas in the wilderness as a portion of a large mineral tract comprising over 30,000 acres. Mineral and oil and gas rights on a 850-acre tract in the headwaters of Dry Branch are owned by D. D. Stewart of Lexington, Ky. Oil and gas leases on Greenwood Land and Mining Company mineral tracts are unassigned at present.

\section{GEOLOGY}

About $555 \mathrm{ft}$ of sedimentary rocks of Late Mississippian to Middle Pennsylvanian age crop out in the study area, and as much as $8,000 \mathrm{ft}$ of older Paleozoic rocks may be in the subsurface (Englund and Teaford, 1981). The lowermost part of the exposed section consists of marine rocks assigned to the Newman Limestone of Late Mississippian age. Outcrops of this formation are limited to the lower valley slopes along Beaver Creek and its tributaries in the northeastern part of the wilderness. The remainder of the exposed stratigraphic section consists mostly of coal-bearing continental rocks assigned to 


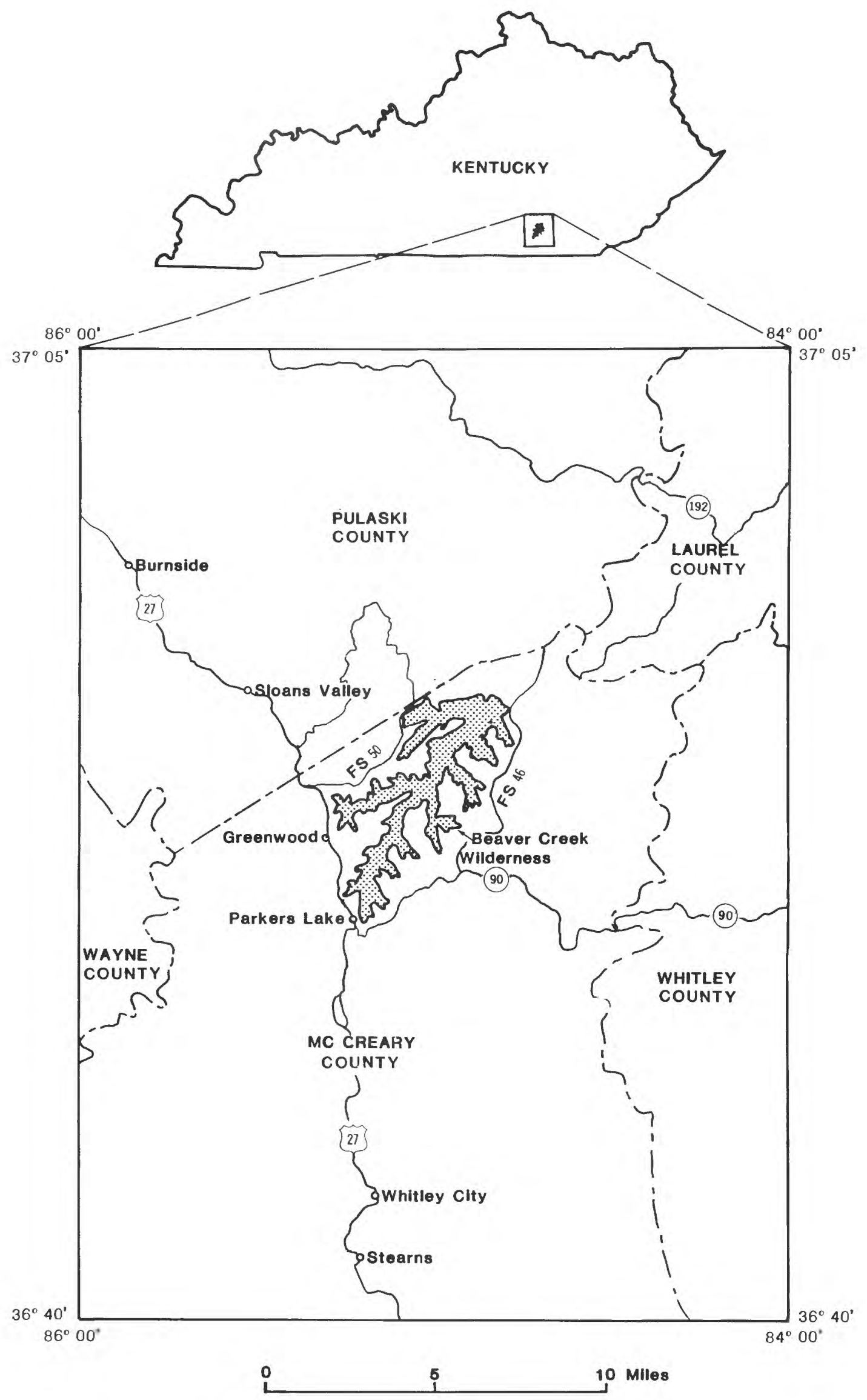

Figure 1.--Index map showing location of the Beaver Creek Wilderness. 


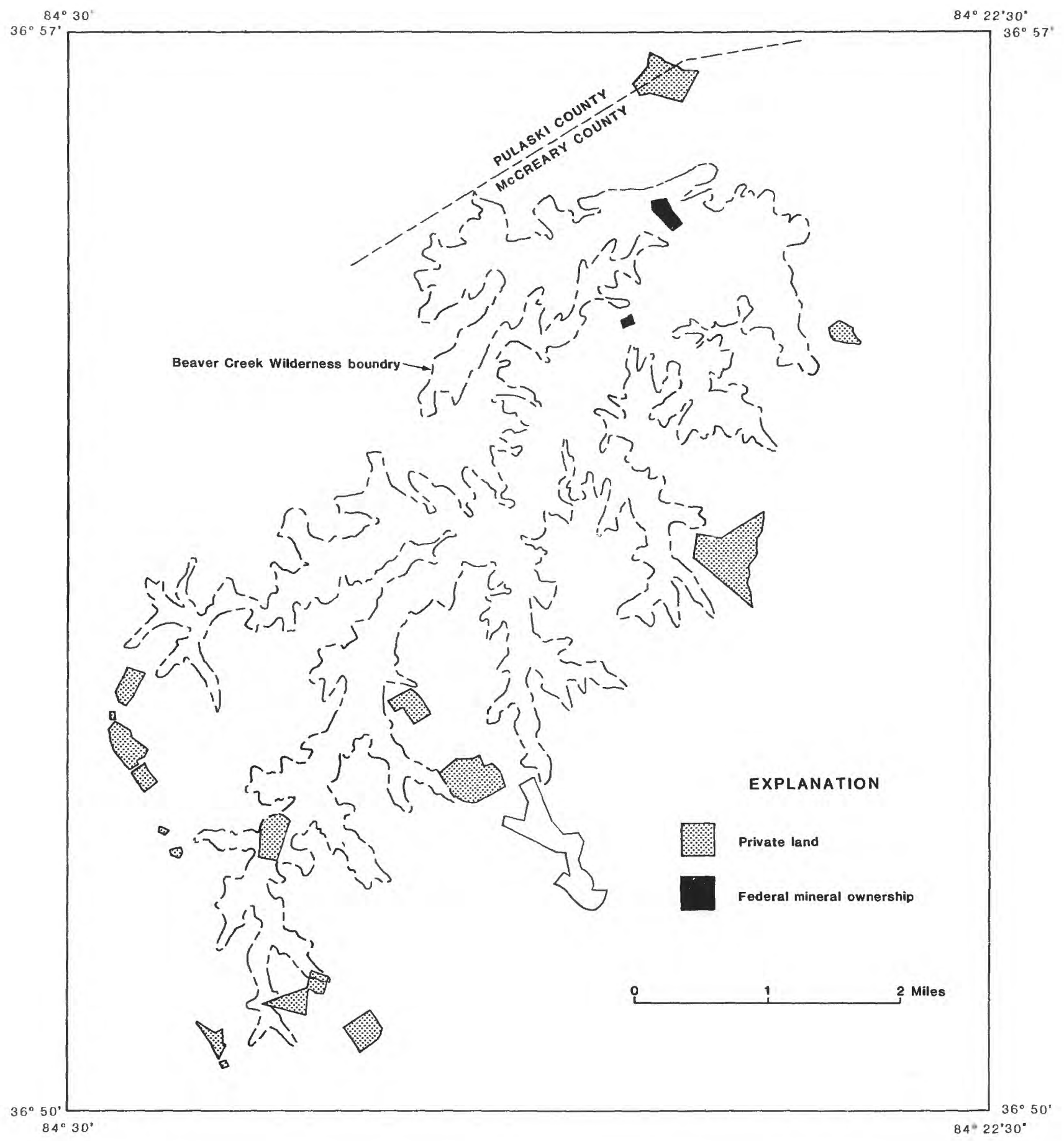

Figure 2.--Land ownership in and adjacent to the Beaver Creek Wilderness. 
the Lee and Breathitt Formations, which also contain several thin brackish-water and marginal marine beds. These formations underlie broad upland areas and crop out extensively along the upper valley slopes of the Beaver Creek drainage. Unmapped surficial deposits consist of colluvium on lower valley slopes and alluvium along the valley floors.

The basal $155 \mathrm{ft}$ of the exposed section are assigned to the Newman Limestone which consists of two members. The lower member is light-olive-gray, thin- to thick-bedded, medium- to coarse-crystalline limestone containing oolites and whole or fragmental marine invertebrate fossils. In this area, a part of the lower member was formerly identified as the Bangor Limestone (Smith and others, 1973). Deposition of the lower member took place in a subtidal to supratidal marine environment. The lower member is conformably overlain by the upper member, which is $125 \mathrm{ft}$ thick and consists of interbedded greenish-gray, grayish-red, and medium-gray shale, argillaceous limestone, and ripple-bedded sandstone. Customarily, the upper member has been referred to as the Pennington Formation by previous workers, including Smith and others (1973). The erroneous application of the name Pennington to the strata of the upper member of the Newman has been common in parts of eastern Kentucky and Tennessee, as pointed out by Englund (1968, p. 12). A few feet of the member, including a thin, ripple-bedded sandstone at the top of the Newman Limestone, may be equivalent to the Pennington, but these beds are too thin to be mapped separately. Deposition of the upper member was largely in a tidal-flat environment but was interrupted by brief marine transgressions as indicated by thin beds of limestone containing marine invertebrate fossils.

The principal coal beds in the Beaver Creek Wilderness are in the Lee Formation of Early and Middle Pennsylvanian age, which disconformably overlies the upper member of the Newman Limestone and typically includes thick beds of conglomeratic orthoquartzite, such as the Rockcastle Sandstone Member. The formation is nearly $400 \mathrm{ft}$ thick and also contains interbedded nonresistant sandstone, siltstone, shale, coal, and underclay. Its Rockcastle Sandstone Member forms precipitous cliffs as high as $200 \mathrm{ft}$ at the periphery of the Beaver Creek Wilderness. For mapping convenience, the Lower Pennsylvanian coalbearing beds beneath the Rockcastle Sandstone Member were included locally in the Breathitt Formation by Smith and others (1973). However, Englund (1968, pl. 5) showed that these beds are laterally equivalent to beds in the type Lee Formation in southwestern Virginia and are not laterally equivalent to beds in the type area of the Breathitt Formation in Breathitt County, Ky. Therefore, they are included here in the Lee Formation. Locally, at the edge of the Beaver Creek Wilderness, the Rockcastle Sandstone Member of the Lee is overlain by underclay, coal, and shale assigned to a tongue of the Breathitt Formation.

Quaternary deposits consist of blocks of locally derived sandstone and conglomeratic sandstone in ummapped deposits of colluvium on the lower valley slopes of Beaver Creek, and of gravel, sand, and silt in alluvium on the valley floors.

The Beaver Creek Wilderness is underlain by relatively flat-lying rocks on the eastern flank of the Cincinnati arch. Structure contour lines drawn on the top of the Rockcastle Sandstone Member of the Lee Formation show that the easterly regional dip is less than $1^{\circ}$ and is modified locally to a northeasterly direction. No evidence of faulting has been observed in the study area.

\section{MINERAL RESOURCE POTENTIAL}

Potential mineral resources in the Beaver Creek Wilderness consist of coal, oil and gas, shale, sandstone, and limestone. High-volatile A bituminous coal has been prospected extensively and mined on a small scale in and near the wilderness. Development of the remaining reserves of coal may be limited by mining technology, extraction costs, and constraints imposed on mining by wilderness and environmental legislation. The potential for oil and gas at shallow depths is largely unproven and the deeper formations are virtually untested. However, a gravity anomaly interpreted as a basement high may provide structural features for hydrocarbon entrapment. Shale in the study area is suitable for various structural clay products and some beds display bloating characteristics that may be adequate for the manufacture of lightweight aggregate. Cut and rough building stone may be provided by several sandstone units cropping out in the area. Limestone crops out near stream level in the northern part of the area; however, much of it is in thin or impure beds, and in those places where high-quality limestone has been identified, it is near water level where quarrying and underground mining operations may not be feasible. Metallic mineral deposits have not been identified in the area, and because major chemical anomalies were not detected in a geochemical survey, a low potential exists for the occurrence of such deposits (Grosz and Siems, 1982).

\section{Coal}

Coal occurs in five beds in and near the wilderness: the Hudson, Stearns No. $11 / 2(?)$, Beaver Creek, Beaver Creek rider, and Barren Fork. Of these, only the Hudson, Beaver Creek, and Beaver Creek rider are of sufficient thickness, extent, and quality for estimation of resources (table 1). Remaining resources total approximately 8.2 million short tons for the three beds and an additional 87 thousand short tons are estimated to have been mined or lost in mining from the Beaver Creek coal bed. Of the estimated total original resources, 48 percent is in the 14- to 28-in. category; 33 percent is in the 28 - to $42-$ in. category; 18 percent is in the 42 -in. category; and 1 percent has been mined. The Beaver Creek coal, the thickest and most persistent bed, contains slightly more than 6 million short tons of coal, or 73 percent of the estimated remaining coal resources. Most remaining coal resources are located in the northern two-thirds of the wilderness (fig. 3 ).

Analyses of coal samples from nearby areas of McCreary County show that the rank of coal in the Hudson and Beaver Creek coal beds is high-volatile A bituminous. On an as-received basis, most of the coal is low in ash (less than 8 percent), moderate to high in sulfur (1.8 to 4.2 percent), and high in heating value (greater than 12,300 Btu/lb). The trace element and major and minor oxide contents of both laboratory coal ash and whole coal do not indicate significant amounts of either potentially toxic or economically valuable trace elements. 


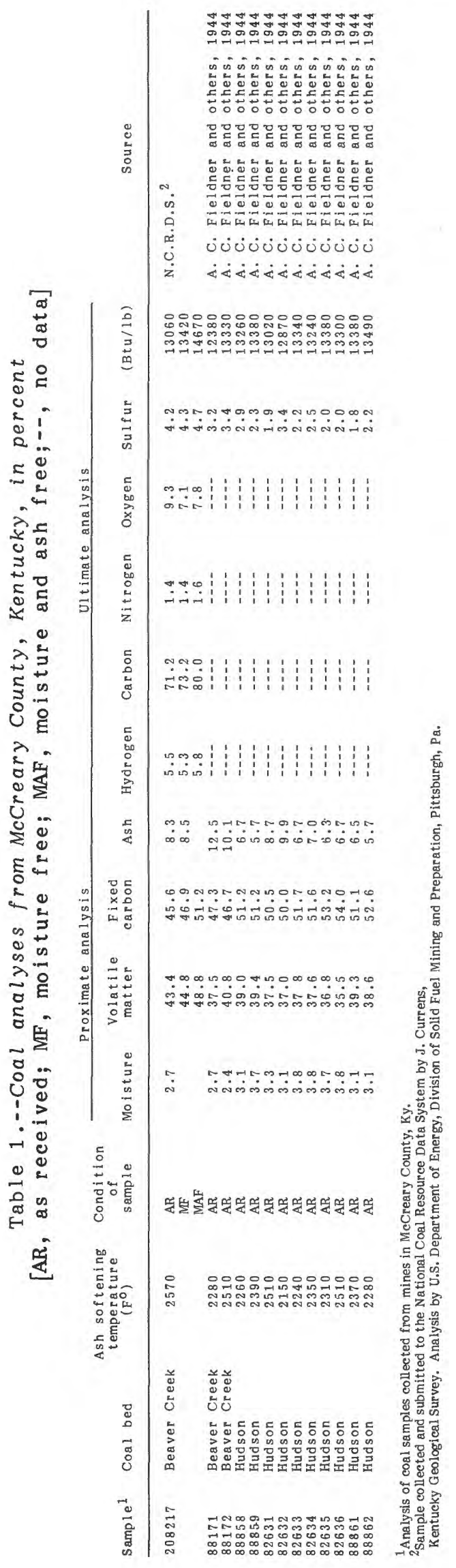




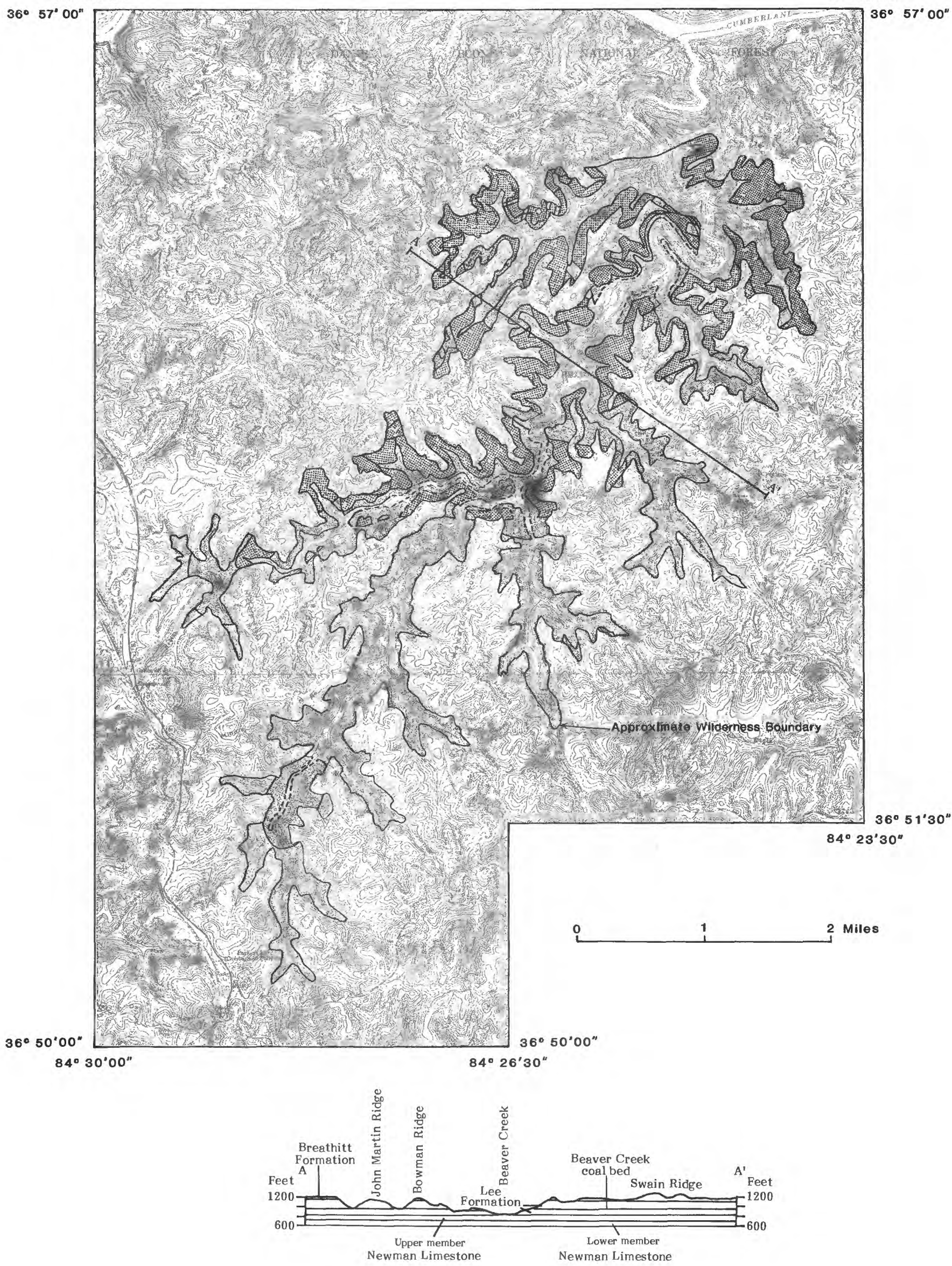


EX P L A N A T I O N

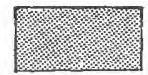

Area underlain by estimated coal resources greater than 42 in. thick

Area underlain by estimated coal resources $28-42$ in. thick

Area underlain by estimated coal resources 14-28 in. thick

Area where coal is absent or less than 14 in. thick

Coal bed outcrop-Dashed where approximately located

Figure 3.--Known cumulative resource distribution of all coal beds in the Beaver Creek Wilderness. Cross section $A-A^{\prime}$ shows geology of the area (from Englund and Teaford, 1981). 
Hudson coal bed-- The Hudson coal bed is approximately 20 to $40 \mathrm{ft}$ above the MississippianPennsylvanian boundary and crops out along the lower valley slopes bordering Beaver Creek and its main tributaries. The coal bed is widespread, but is generally less than 12 in. thick. Estimated resources, limited to the 14- to 28-in. category, are in three blocks that are oriented along a northeasterly trend through the central part of the area. Estimated original and remaining resources in the Hudson coal bed are 1,960 thousand short tons.

Stearns No. $11 / 2($ ?) coal bed - A thin coal bed that locally lies 10 to $20 \mathrm{ft}$ below the Beaver Creek coal bed is tentatively identified as the Stearns No. 1 $1 / 2($ ?). It does not contain identified coal resources greater than 14 in. thick within the wilderness.

Beaver Creek coal bed - On the basis of available information, only the Beaver Creek coal bed contains coal reserves within the wilderness. It ranges from 3 to 62 in. thick and most of the thick coal is in the northern half of the area. A few inches of cannel coal and one or two carbonaceous shale partings from $1 / 4$ to 2 in. thick commonly occur in the upper 8 in. of the bed. Locally, the basal 10 in. contains one or more clay partings ranging from $1 / 2$ to 2 in. thick. The roof-rock is generally medium-gray shale but also consists of fine- to medium-grained sandstone in the northern part of the area. A light- to medium-gray underclay underlies the coal except along Middle Fork where a siltstone with fossil rootlets is present.

Estimated remaining coal resources in the Beaver Creek coal bed are slightly less than 6.1 million short tons. All coal within the wilderness boundary considered minable by contemporary mining methods is categorized in the "wilderness remaining reserve base" of the Beaver Creek bed, which is estimated to be slightly less than 4.2 million short tons by underground mining, 453 thousand short tons by strip mining, and 541 thousand short tons by auger mining. The "impacted remaining reserve base," which includes all coal in the wilderness and on contiguous mineral tracts that cannot be mined except from drift entries and surface mines within the wilderness boundary, is estimated to be about 8.7 million short tons. All strip and auger minable coal is essentially within the wilderness boundary.

Small tonnages of potentially minable coal are in blocks, containing coal 24 to 28 in. thick lying adjacent to thicker blocks that may be mined. Coal beneficiation would be necessary to remove impurities introduced by mining the roof and floor to attain mine height. Potentially minable coal is estimated to be 1.6 million short tons.

A specific recovery factor for modern underground mining of the Beaver Creek coal bed has not been demonstrated. Recovery factors vary in response to local geologic conditions, mine development plans, and capabilities of the mining equipment. However, a 50 percent recovery factor indicates remaining reserves of less than 4.4 million short tons of impacted coal and 2.1 million short tons of "wilderness" coal; at 60 percent recovery, remaining reserves of 5.2 million short tons of impacted coal and 2.5 million short tons of "wilderness" coal are indicated. Strip and auger reserves were derived from the reserve base using a 78.6 percent recovery factor for strippable coal and a 33 percent recovery factor for auger minable coal. Strip and auger remaining reserves for the Beaver Creek coal bed are 356 thousand short tons and $\mathbf{1 7 9}$ thousand short tons, respectively.

Beaver Creek rider coal bed -- The Beaver Creek rider coal bed lies 35 to $60 \mathrm{ft}$ above the Beaver Creek coal and ranges from 0 to 28 in. in thickness. In much of the area the bed was eroded prior to the deposition of the overlying sandstone. Two small blocks of coal at the northwestern and southeastern edges of the area contain a total estimated original and remaining resource of 249 thousand short tons.

Barren Fork coal bed - The Barren Fork coal is a persistent bed as much as 48 in. thick at the base of the Breathitt Formation. It lies above the Rockcastle Sandstone Member of the Lee Formation and is widely distributed in the uplands fringing the wilderness boundary. For this reason, the bed does not contain estimated resources in the wilderness area.

\section{Shale}

Preliminary ceramic tests indicate that shale from the Lee Formation and the upper member of the Newman Limestone may be suitable for structural clay products such as building, face, and decorative brick, and wall, floor, roofing, and hollow tile. A shale sample from the upper member of the Newman Limestone also bloated during quick-fire tests indicating that it may be suitable for the manufacture of lightweight aggregate. Because these shale resources are limited in extent and thickness by interbedded sandstone and siltstone, foreseeable demand could be met by better quality and more accessible deposits outside of the wilderness.

\section{Sandstone}

Analyses indicate that the high-silica Rockcastle Sandstone Member of the Lee Formation is suitable for use as furnace, engine, asphaltic, grouting, brick mortar, and low-grade glass sand. Locally, this sandstone qualifies for use as bed, concrete, roofing, and filter sand and in other applications as pulpstone, sand-lime brick, and fluxing quartz. Building stone can also be obtained from this sandstone where conglomerate is not detrimental to appearance. The even-textured upper part of the Rockcastle Sandstone Member has been quarried for dimension stone about 3 mi southwest of the wilderness. In general, the potential for commercial utilization of sandstone from the Beaver Creek Wilderness is low because better quality and more accessible deposits are available outside the area.

\section{Oil and Gas}

Sedimentary rocks underlying the Beaver Creek Wilderness are similar to those in nearby areas that contain commercial quantities of oil and gas. According to Smith (1970), most tests have been drilled so as to penetrate the Lower Mississippian Fort Payne Formation which includes the "Beaver sand" of drillers. Drilling depths ranged mostly from 700 to $1,100 \mathrm{ft}$ and few wells produced more than 10 barrels per day. In 1960 a test hole was drilled near Wiborg, Ky., about $2 \mathrm{mi}$ south of the wilderness, to a depth of $1,600 \mathrm{ft}$ and was deepened in 1963 to a depth of 2,926 ft. It probably bottomed in the Knox Group of Cambrian and Ordovician age and was abandoned as a dry hole (Smith, 1970). The oil and gas potential of the 
Beaver Creek Wilderness has not been demonstrated and exploration in nearby areas is too shallow or widely spaced to adequately test the sedimentary sequence.

\section{REPERENCES CITED}

Collier, C. R., and others, 1964, Influences of strip mining on the hydrologic environment of parts of Beaver Creek basin, Kentucky, 1955-59: U.S. Geological Survey Professional Paper 427-B, $85 \mathrm{p}$.

Collier, C. R., Pickering, R. J., and Musser, J. J., eds., 1970, Influences of strip mining on the hydrologic environment of parts of Beaver Creek basin, Kentucky, 1955-66: U.S. Geological Survey Professional Paper 427-C, $80 \mathrm{p}$.

Englund, K. J., 1968, Geology and coal resources of the Elk Valley area, Tennessee and Kentucky: U.S. Geological Survey Professional Paper 572, 59 p.

Englund, K. J., and Teaford, N. K., 1981, Geologic map of the Beaver Creek Wilderness, McCreary County, Kentucky: U.S. Geological Survey Miscellaneous Field Studies Map MF-1348-A, scale $1: 50,000$.

Grosz, A. E., and Siems, D. F., 1982, Geochemical survey of the Beaver Creek Wilderness, McCreary County, Kentucky: U.S. Geological Survey Miscellaneous Field Studies Map MF-1348-B, scale 1:50,000.
Hammack, R. W., in press, Maps showing mines, prospects, and exposures in the Beaver Creek Wilderness, McCreary County, Kentucky: U.S. Geological Survey Miscellaneous Field Studies Map MF-1348-C, scale 1:50,000.

Huddle, J. W., Lyons, E. J., Smith, H. L., and Ferm, J. C., 1963, Coal reserves of eastern Kentucky: U.S. Geological Survey Bulletin 1120, 247 p.

Miller, A. M., 1910, Coals of the lower measures along the western border of the Eastern coal field: Kentucky Geological Survey Bulletin 12, 83 p.

Murphy, R. E., and Miller, R., 1949, Structural and areal geology of McCreary County, Kentucky: Kentucky Geological Survey, ser. V1 (reprinted without revision from ser. Vl, 1928).

Musser, J. J., 1963, Description of physical environment and of strip-mining operations in parts of Beaver Creek basin, Kentucky: U.S. Geological Survey Professional Paper 427-A, 25 p.

Smith, J. H., 1970, Geologic map of the Wiborg quadrangle, McCreary County, Kentucky: U.S. Geological Survey Geologic Quadrangle Map GQ-867, scale 1:24,000.

Smith J. H., Pomerene, J. B., and Ping, R. G., 1973, Geologic map of the Hail quadrangle, McCreary and Pulaski Counties, Kentucky: U.S. Geological Survey Geologic Quadrangle Map GQ-1058, scale $1: 24,000$. 